\title{
Interleukin 10 Measurement
}

National Cancer Institute

\section{Source}

National Cancer Institute. Interleukin 10 Measurement. NCI Thesaurus. Code C74806.

The determination of the amount of interleukin 10 present in a sample. 